\title{
Chemical constituents of Eruca sativa and treatment activity against paracetamol inducing hepatic injury in experimental rats
}

\author{
M.F.ELSadek \\ Nutrition and Food Science Department, Faculty of Home Economics, \\ Helwan University.
}

\begin{abstract}
In the present study, gross chemical composition and some minerals content of Eruca sativa leaves and seeds were estimated. Also, hepatotreatment activity of Eruca sativa leaves, juice, oil and seeds against paracetamol induced liver damage in rats were investigated. Results of this study revealed that Eruca sativa (rocket salad) seeds had higher content of protein, fat and carbohydrate and minerals ( $\mathrm{Zn}, \mathrm{Fe}, \mathrm{Ca}, \mathrm{K}$ and $\mathrm{Cu})$. Eruca sativa leaves had higher content of fibre, ash and moisture. Paracetamol induced liver injury rat groups treated with Eruca sativa leaves, juice, oil and seeds improved weight gain percent and food intake that appeared within normal. However, they decreased total serum protein and urea with significant increase in total bilirubin, haemoglobin $(\mathrm{Hb})$ and packed cell volume (PCV) compared with control (+ve) group. Moreover, they lowered liver function enzymes, liver cholesterol, total lipids and MDA and elevated liver triglyceride, glycogen and liver antioxidant enzymes compared with control (+ve) group.
\end{abstract}

In conclusion, Eruca sativa could could help the liver against paracetamol induced hepatic injury through its potent antioxidant activity in rats.

Keywords: Eruca sativa; Liver Injury; paracetamol; liver enzymes; antioxidant; rats.

\section{Introduction}

Liver plays a pivotal role in regulating various physiological processes in the body. It is involved in several vital functions, such as metabolism, secretion and storage and also detoxification and synthesizes useful principles. Hepatotoxic agents cause structural abnormality in the liver which alters normal physiological functions. Plant derived natural products such as flavonoids, terpenoids and steroids have received considerable attention in recent years due to their diverse pharmacological properties including antioxidant and hepatoprotective activity (Eisenberg et al., 1998 and Stickel and Schuppan 2007).

Medicinal plants may serve as a vital source of potentially useful new compounds for the development of effective therapy to combat a variety of liver problems. Eruca sativa (syn. E. vesicaria subsp. sativa (Miller) Thell.) is an edible annual plant, often weedy, belongs to the Brassicaceae family of plants that originated in the Mediterranean region and Western Asia, and is now widely cultivated for its piquant leaves which are used in salads and as a cooked green. Eruca sativa is known as salad rocket because of their strong flavour and their content of putative health-promoting compounds. Among such compounds, glucosinolates and phenolics are well-known phytochemicals with an important role in determining the characteristic flavour of these species (Lazzeri et al., 2004 and Pasini et al., 2011).

In Asia, Eruca sativa has typically been cultivated for its seed oil for culinary purposes including pickling as well as industrial uses as a lubricant and as a source of erucic acid used in oil paints and as a lubricant. In traditional 


\section{M.F.ELSadek}

medicine, Eruca sativa has been used as a stimulant and diuretic, and to treat stomach disorders. Eruca sativa (rocket) contains a wide range of compounds with nutraceutical and organoleptical properties (Flanders and AbdulKarim 1985). It has diversified medicinal and therapeutic properties including inhibition of tumorigenesis, anti-ulcer, and hepatoprotective activities (Lynn et al., 2006 and Alqasoumi et al., 2009). The rocket seeds and tender leaves are known in Arabian countries to increase sexual desire and are considered to be an aphrodisiac. Eruca sativa exert a beneficial antidiabetic effect in rats by reducing oxidative stress. It is also used as a carminative and to alleviate abdominal discomfort and improve digestion. The seed ethanolic extract possesses potent antioxidant and renal protective and diuretic activities (Yanir et al., 1998, Sarwar et al., 2007 and Ansari 2014).

This research aimed to investigate the chemical constituents of Eruca sativa and treatment activity against paracetamol induced hepatic injury in rats.

\section{Materials and Methods}

\section{A-Materials:}

Fresh leaves of Eruca sativa were obtained from grocery in Cairo while seeds and oil of E. sativa were purchased from the local herbal store. Specimens were identified in Taxonomy Lab. in the Department of Botany, Agriculture faculty, Cairo University. Paracetamol drug was obtained from Kahira Pharm \&Chem. Ind. Co., Cairo- Egypt. Kits for biochemical analysis were purchased from the Gamma Trade Company for Pharmaceutical and Chemicals, Dokki, Egypt. Forty eight adult male of white albino rats (Sprague dawley strain), weighing $185 \pm 5 \mathrm{~g}$. were obtained from of National Research Center, Cairo, Egypt. The rat basal diet was performed according to Reeves et al., (1993).

\section{B- Methods :}

1-Chemical study:

The fresh Eruca sativa leaves were washed with tap water, part of them was ground in a blender and filtered by using funnel and filter paper to obtain juice while other part was dried with hot air oven $\left(40-60^{\circ} \mathrm{C}\right)$ and grinded to powder. Eruca sativa seeds were ground into powder form by using electrical grinder to fine particles (A.O.A.C., 2005). Proximate analysis of Eruca sativa leaves and seeds powder samples consists of moisture, total fat, protein, ash, fibre and carbohydrate content were estimated according to Duke and Atchley (1984). Some minerals as $\mathrm{Zn}, \mathrm{Fe}, \mathrm{Ca}, \mathrm{K}$ and $\mathrm{Cu}$ were also determined according to Pupsa et al., (1994).

\section{2- Biological design}

After a week for adaptation period, rats were housed as six groups ( 8 rats each) in wire cages under the normal laboratory conditions. First group was kept as normal group (- ve control ) and the others were given a single dose of $2 \mathrm{~g} / \mathrm{kg}$ of paracetamol by stomach tube for each rat to induce liver injury (Rafael et al., 1999). Groups of rats with baracetamol induced liver injury were divided into control +ve group and four treated groups with Eruca sativa leaves powder ( $5 \%$ instead of diet cellulose), juice $(300 \mathrm{mg} / \mathrm{kg}$ orally), oil (3ml $/ \mathrm{kg}$ orally) and seeds powder ( $5 \%$ instead of diet cellulose). Daily food intake, weekly body weight gain and feed efficiency ratio (FER) were determined according to Chapman et al., (1950). At the end of experimental period (42days), rats were anesthetized and blood sample were collected from hepatic portal vein in clean centrifuge tubes. Liver was removed and blotted on filter paper.

\section{4- Biochemical analysis:}

The packed cell volume (PCV) was determined by the microhaematocrit method and the haemoglobin $(\mathrm{Hb})$ concentration by the cyanmethaemoglobin method according to Mc Inory (1954) and Vankampen and Ziglstra (1961), respectively. 


\section{Egypt. J. of Nutrition and Health Vol. 9 No. 1 (2014)}

The blood was left to coagulate then centrifuged at $3000 \mathrm{rpm}$ for 15 minutes to obtain serum. Serum total bilirubin, total protein and urea were determined according to Jendrassik (1938) Weichselbaum (1946), and Patton and Crouch (1977), respectively.Serum aspartate and alanine aminotransferase (AST, ALT) activity, alkaline phosphatase (ALP) and gamma glutamyle transferase (YGT) enzymes activity were estimated according to Reitman and Frankel (1957), Kind and King (1954) and Meister et al., (1981), respectively. Liver cholesterol, total lipids, triglyceride and glycogen were determined according to Richmond (1973), Folch et al., (1957), Scheletter and Nussel (1975) and Rerup and Lundquist (1967), respectively. Liver glutathione S-transferase (GST), superoxide dismutase (SOD), glutathione peroxidase (GPX), and malondialdehyde (MDA) were estimated according to Ellman (1958), Beuchamp and Fridovich (1971), Weiss et al.,(1980), and Uchiyama and Mihara (1978), respectively.

\section{Statistical analysis}

Data are expressed as mean \pm SD. Statistical analysis was done by using analysis of variance (ANOVA) followed by student's t-test and $P$ values of $5 \%$ and less were considered to be significant according to Artimage and Berry (1987).

\section{Results}

Table (1)

Gross chemical composition of Eruca sativa seeds and leaves powder (\%)

\begin{tabular}{|c|c|c|c|c|c|c|}
\hline & Protein & Fat & Fibre & Ash & Moisture & carbohydrate \\
\hline Seeds & 25.77 & 26.11 & 3.12 & 9.11 & 10.77 & 25.12 \\
\hline Leaves & 15.96 & 1.06 & 15.66 & 10.71 & 25.67 & 24.95 \\
\hline
\end{tabular}

The chemical composition of $E$. sativa leaves and seeds was illustrated in table 1. Eruca sativa (rocket salad) seeds had higher content of crude protein, fat and carbohydrate $(25.77,26.11$, and 25.12 , respectively) than rocket salad leaves. However, higher content of fibre, ash and moisture as the value being $15.66,10.71$ and $25.67 \%$ was found in Eruca sativa leaves.

Table (2)

Some mineral content of Eruca sativa seeds and leaves powder $(\mu \mathrm{g} / \mathrm{g})$

\begin{tabular}{|c|c|c|c|c|c|}
\hline & $\mathrm{Zn}$ & $\mathrm{Fe}$ & $\mathrm{Ca}$ & $\mathrm{K}$ & $\mathrm{Cu}$ \\
\hline Seeds & 50.66 & 58.56 & 1805.66 & 703.65 & 30.66 \\
\hline Leaves & 1.25 & 35.71 & 655.66 & 319.96 & 19.77 \\
\hline
\end{tabular}

Table 2 showed that seeds of Eruca sativa had higher content of minerals as the values of $\mathrm{Zn}, \mathrm{Fe}, \mathrm{K}$ and $\mathrm{Cu}$ were $50.66,58.56,703.65$ and $30.66 \mu \mathrm{g} / \mathrm{g}$, respectively than Eruca sativa leaves. However, Eruca sativa leaves had lower content of $\mathrm{Ca}$ as the value was $655.66 \mu \mathrm{g} / \mathrm{g}$. 
Table (3)

The Mean values \pm SD of weight gain, weight gain $\%$, food intake and FER of the experimental groups

\begin{tabular}{|c|c|c|c|c|c|}
\hline & & Weight gain & Weight gain \% & Food intake & FER \\
\hline \multicolumn{2}{|c|}{ Normal } & $85.77 \pm 8.20 \mathrm{a}$ & $46.11 \pm 5.10 \mathrm{a}$ & $20.71 \pm 1.21 a$ & $0.098 \pm 0.001 a$ \\
\hline \multicolumn{2}{|c|}{ Control +ve } & $20.77 \pm 1.17 d^{\star \star \star}$ & $11.10 \pm 0.88 b^{\star \star}$ & $17.77 \pm 1.40 b^{\star \star}$ & $0.027 \pm 0.003 d^{\star \star \star}$ \\
\hline \multirow{4}{*}{ 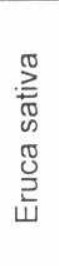 } & Leaves & $60.77 \pm 2.55 b c^{\star \star}$ & $32.32 \pm 3.01 \mathrm{a}$ & $19.55 \pm 1.37 a$ & $0.074 \pm 0.004 c^{\star \star}$ \\
\hline & Juice & $65.96 \pm 4.66 b^{\star \star}$ & $35.27 \pm 2.96 a$ & $19.91 \pm 1.40 \mathrm{a}$ & $0.078 \pm 0.002 c^{\star \star}$ \\
\hline & Oil & $72.66 \pm 6.80 a b$ & $38.64 \pm 3.16 a$ & $20.11 \pm 1.67 a$ & $0.086 \pm 0.005 b^{*}$ \\
\hline & Seeds & $70.11 \pm 6.8 \mathrm{ab}$ & $37.09 \pm 3.11 \mathrm{a}$ & $19.54 \pm 1.31 \mathrm{a}$ & $0.085 \pm 0.006 b^{*}$ \\
\hline
\end{tabular}

Significant difference with control (-ve) group * $P<0.05^{* \star} P<0.01{ }^{* * \star} P<0.001$

Values with the same letters in column indicate non- significant difference $(P>0.05)$

Data in table 3 represent the paracetamol induced liver injury in rats the control +ve group showed significant decrease in weight gain $(P<0.001)$, weight gain \% $(P<0.01)$, food intake $(P<0.01)$ and $F E R(P<0.001)$ compared with normal control ( - ve ) group. Rat groups with liver injury when treated with Eruca sativa leaves powder and juice showed significant decrease in weight gain $(P<0.01)$ and FER $(P<0.01)$ while rat groups treated with Eruca sativa oil and seeds powder showed less significant decrease $(P<0.05)$ compared with normal control group. Treatment rat groups with Eruca sativa leaves, juice, oil and seeds could improve weight gain \% and food intake that appeared close to normal values and also increase weight gain and FER compared with control (+ve) group. The most favourable results appeared in rat groups treated with Eruca sativa oil and seeds.

Table (4)

The Mean values \pm SD of total protein, total bilirubin, urea, $\mathrm{Hb}$ and $\mathrm{PCV}$ of the experimental groups

\begin{tabular}{|c|c|c|c|c|c|c|}
\hline & & $\begin{array}{c}\text { Total protein } \\
\text { (g/dl) }\end{array}$ & $\begin{array}{l}\text { Total bilirubin } \\
(\mathrm{g} / \mathrm{dl})\end{array}$ & $\begin{array}{c}\text { Urea } \\
(\mu / \mathrm{mg})\end{array}$ & $\begin{array}{c}\mathrm{Hb} \\
(\mathrm{g} / \mathrm{dL})\end{array}$ & $\begin{array}{l}\text { PCV } \\
(\%)\end{array}$ \\
\hline \multicolumn{2}{|c|}{ Normal } & $0.55 \pm 0.08 d$ & $7.33 \pm 0.44 a$ & $19.55 \pm 1.70 \mathrm{c}$ & $13.67 \pm 1.18 a$ & $35.71 \pm 3.41 a$ \\
\hline \multicolumn{2}{|c|}{ Control (+ve) } & $2.11 \pm 0.10 a^{\star \star \star}$ & $5.11 \pm 0.52 b^{\star \star \star}$ & $44.71 \pm 4.03 a^{\star *}$ & $9.54 \pm 1.03 b^{\star \star \star}$ & $27.71 \pm 2.66 c^{\star \star \star}$ \\
\hline \multirow{4}{*}{ 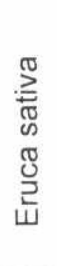 } & Leaves & $0.66 \pm 0.02 c^{*}$ & $7.14 \pm 0.80 a$ & $26.71 \pm 2.66 b^{\star}$ & $12.66 \pm 1.11 a$ & $32.33 \pm 3.16 a b$ \\
\hline & Juice & $0.61 \pm 0.04 \mathrm{~cd}$ & $6.49 \pm 0.66 a$ & $21.71 \pm 2.15 c$ & $13.21 \pm 1.16 a$ & $43.71 \pm 3.61 a$ \\
\hline & Oil & $0.75 \pm 0.01 b^{*}$ & $6.45 \pm 0.87 a$ & $23.14 \pm 2.19 b c$ & $12.33 \pm 1.14 \mathrm{a}$ & $31.21 \pm 3.24 a$ \\
\hline & Seeds & $0.88 \pm 0.02 b^{\star \star}$ & $6.77 \pm 0.88 a$ & $25.11 \pm 3.20 b^{\star}$ & $12.11 \pm 1.15 a$ & $33.60 \pm 2.96 a$ \\
\hline
\end{tabular}

Significant difference with control (-ve) group ${ }^{\star} P<0.05^{\star \star} P<0.01 \quad{ }^{\star \star \star} P<0.001$

Values with the same letters in column indicate non- significant difference $(P>05)$ and vice versa

The activities of total serum protein and urea were significantly increased at $p<0.001 \& 0.01$, respectively and significant decrease in total bilirubin, $\mathrm{Hb}$ and PCV at $\mathrm{p}<0.001$ in control (+ve) group compared with normal ( control -ve ) group. Liver injury rat groups treated with Eruca sativa leaves and seeds powder showed significant increase in total 


\section{Egypt. J. of Nutrition and Health Vol. 9 No. 1 (2014)}

protein $(p<0.05 \& 0.01)$ and urea $(p<0.05)$ and non significant decrease total bilirubin, $\mathrm{Hb}$ and $\mathrm{PCV}$ at $\mathrm{p}>0.05$ while rat groups treated with Eruca sativa oil showed significant increase in total protein $(p<0.05)$ and non significant decrease total bilirubin, $\mathrm{Hb}$ and PCV and also non significant increase in urea at $p>0.05$ compared with normal control group. Rat groups treated with Eruca sativa juice showed that the values of the above mentioned parameters were within normal. Treatment rat groups with Eruca sativa leaves, juice, oil and seeds could decrease total protein and urea and significant increase in total bilirubin, $\mathrm{Hb}$ and PCV compared with control (+ve) group. The best results appeared in rat groups treated with Eruca sativa juice as shown in table 4.

Table (5)

The Mean values \pm SD of ALT, AST, ALP and $Y$ GT of the experimental rat groups

\begin{tabular}{|c|c|c|c|c|c|}
\hline & & $\operatorname{ALT}(\mu / \mathrm{ml})$ & $\operatorname{AST}(\mu / \mathrm{ml})$ & $\operatorname{ALP}(\mu / \mathrm{ml})$ & y GT $(\mu / \mathrm{ml})$ \\
\hline \multicolumn{2}{|c|}{ Normal } & $45.11 \pm 5.31 \mathrm{c}$ & $50.51 \pm 5.57 c$ & $40.31 \pm 4.11 \mathrm{c}$ & $7.31 \pm 1.43 c$ \\
\hline \multicolumn{2}{|c|}{ Control +ve } & $139.91 \pm 17.36 \mathrm{a}^{\star \star \star}$ & $145.41 \pm 11.20 a^{\star \star \star}$ & $120.77 \pm 10.71 a^{\star \star \star}$ & $18.31 \pm 1.21 a^{\star \star *}$ \\
\hline \multirow{4}{*}{ 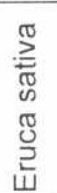 } & Leaves & $56.77 \pm 6.24 b^{\star}$ & $63.77 \pm 6.31 b^{*}$ & $61.91 \pm 6.21 b^{*}$ & $10.22 \pm 1.96 b^{\star}$ \\
\hline & Juice & $53.27 \pm 6.70 b c$ & $59.14 \pm 6.41 b c$ & $60.41 \pm 6.71 b^{*}$ & $9.50 \pm 1.67 b c$ \\
\hline & Oil & $54.35 \pm 5.66 b c$ & $60.14 \pm 6.61 b c$ & $50.21 \pm 5.41 c$ & $9.14 \pm 1.72 b c$ \\
\hline & Seeds & $59.61 \pm 6.20 b^{*}$ & $65.11 \pm 6.03 b^{\star}$ & $55.11 \pm 5.31 b c$ & $10.81 \pm 1.84 b^{\star}$ \\
\hline
\end{tabular}

Significant difference with control (-ve) group * $P<0.05^{\star \star *} \mathrm{P}<0.01{ }^{* \star *} \mathrm{P}<0.001$

Values with the same letters in column indicate non- significant difference $(P>0.05)$

Table 5 showed that the activities of serum ALT, AST, ALP and YGT enzymes were highly significant increased in paracetamol induced liver injury rat group (control $+v e$ ) at $p<0.001$ and in liver injury rat group treated with Eruca sativa leaves powder at $p<0.05$ compared to rats of normal group. Liver injury rat group treated with Eruca sativa juice showed significant increase in ALP at $p<0.05$ and non significant increase in ALT, AST and yGT enzymes however liver injury rat group treated with Eruca sativa seeds powder showed significant increase in ALT, AST and yGT enzymes at $p<0.05$ and non significant increase ALP compared to rats of normal group. Rat groups treated with Eruca sativa oil showed that liver function enzymes were within normal. Treatment rat groups with Eruca sativa leaves, juice, oil and seeds could lower these enzymes and improve liver function compared with control (+ve) group.

Table (6)

The Mean values \pm SD of liver cholesterol, total lipid, triglyceride and glycogen of the experimental rat groups

\begin{tabular}{|c|c|c|c|c|c|}
\hline & & Cholesterol $(\mathrm{mg} / \mathrm{g})$ & Total lipids(mg/g) & Triglyceride $(\mathrm{mg} / \mathrm{g})$ & Glycogen $(\mathrm{mg} / \mathrm{g})$ \\
\hline \multicolumn{2}{|c|}{ Normal (-ve) } & $3.79 \pm 0.69 b c$ & $36.71 \pm 3.20 \mathrm{bc}$ & $3.56 \pm 0.25 a$ & $5.99 \pm 0.56 a$ \\
\hline \multicolumn{2}{|c|}{ Control +ve } & $6.96 \pm 1.21 a^{\star \star \star}$ & $55.71 \pm 5.26 \mathrm{a}^{\star \star \star}$ & $1.49 \pm 0.11 c^{\star \star \star}$ & $2.89 \pm 0.23 c^{\star \star \star}$ \\
\hline \multirow{4}{*}{ 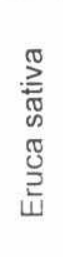 } & Leaves & $4.61 \pm 0.54 b$ & $39.60 \pm 3.18 b$ & $3.07 \pm 0.24 b^{\star}$ & $4.51 \pm 0.56 a b$ \\
\hline & Juice & $4.21 \pm 0.58 b$ & $35.60 \pm 4.01 \mathrm{bc}$ & $3.17 \pm 0.23 a b$ & $4.60 \pm 0.44 a b$ \\
\hline & Oil & $4.31 \pm 0.65 b$ & $40.21 \pm 3.99 b$ & $3.12 \pm 0.19 a b$ & $4.31 \pm 0.54 a b$ \\
\hline & Seeds & $4.11 \pm 0.72 b$ & $41.21 \pm 4.52 b$ & $3.14 \pm 0.14 \mathrm{ab}$ & $4.11 \pm 0.60 \mathrm{ab}$ \\
\hline
\end{tabular}

Significant difference with control (-ve) group ${ }^{\star} P<0.05^{* \star} P<0.01{ }^{\star \star \star} P<0.001$ 


\section{M.F.ELSadek}

Values with the same letters in column indicate non- significant difference $(P>0.05)$

Paracetamol administration could increase the levels of liver cholesterol and total lipids and decrease triglyceride and glycogen at $p<0.001$ compared with the control (-ve) rat group. Liver injury rat group which treated with Eruca sativa leaves powder showed non significant increase in the levels of liver cholesterol, total lipids and glycogen and significant decrease in triglyceride at $p<0.05$ compared to rats of normal ( -ve ) group. However, Liver injury rat groups treated Eruca sativa, juice, oil and seeds showed normal values of these parameters. Treatment rat groups with Eruca sativa leave, juice, oil and seeds could lower the levels of liver cholesterol and total lipids and increase triglyceride and glycogen compared with control (+ve) group as illustrated in table 6.

Table (7)

Mean values \pm SD of liver GST, SOD, GPX and MDA of the experimental rat groups (mmol/l)

\begin{tabular}{|c|c|c|c|c|c|}
\hline & & $\operatorname{GST}(\mu / \mathrm{mg})$ & $\operatorname{SOD}(\mu / \mathrm{mg})$ & $\operatorname{GPX}(\mu / \mathrm{mg})$ & $\mathrm{MDA}(\mathrm{mmol} / \mathrm{l})$ \\
\hline \multicolumn{2}{|c|}{ Normal } & $1.35 \pm 0.03 a$ & $55.16 \pm 5.10 a$ & $49.41 \pm 4.27 a$ & $8.66 \pm 1.17 b$ \\
\hline \multicolumn{2}{|c|}{ Control +ve } & $0.65 \pm 0.002 d^{\star \star \star}$ & $22.24 \pm 2.11 c^{\star \star \star}$ & $20.55 \pm 2.66 c^{\star \star \star}$ & $17.85 \pm 2.41 a^{\star \star \star}$ \\
\hline \multirow{4}{*}{ 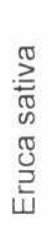 } & Leaves & $0.89 \pm 0.004 b c^{\star \star}$ & $41.21 \pm 4.17 b^{*}$ & $35.16 \pm 3.66 b^{\star}$ & $9.11 \pm 1.03 b$ \\
\hline & Juice & $1.01 \pm 0.05 a b$ & $49.61 \pm 4.22 \mathrm{ab}$ & $40.71 \pm 5.11 a b$ & $8.21 \pm 1.15 b$ \\
\hline & Oil & $0.91 \pm 0.02 b^{\star}$ & $47.21 \pm 5.14 \mathrm{ab}$ & $39.61 \pm 4.71 \mathrm{ab}$ & $9.11 \pm 1.14 b$ \\
\hline & Seeds & $0.95 \pm 0.03 b^{*}$ & $43.21 \pm 3.15 b^{\star}$ & $37.61 \pm 4.50 b^{\star}$ & $9.66 \pm 1.10 b$ \\
\hline
\end{tabular}

Significant difference with control $(-v e)$ group ${ }^{\star} P<0.05{ }^{\star \star} P<0.01 \quad{ }^{\star \star \star} P<0.001$

Values with the same letters in column indicate non- significant difference $(P>0.05)$

On paracetamol administration ( control + ve ) showed lower values of antioxidant liver enzymes as GST, SOD and GPX but showed higher value of MDA at $p<0.001$ compared with normal ( control - ve ) group. Liver injury rat groups treated with Eruca sativa leaves and seeds showed significant decrease in the levels of liver antioxidant enzymes and non significant increase in the value of MDA compared to rats of normal group. However, Liver injury rat groups treated with Eruca sativa juice showed normal values of these parameters while rat group treated with Eruca sativa oil showed significant decrease in the levels of liver GST, non significant decrease in the value of SOD and GPX and non significant increase in the value of MDA compared to rats of normal (-ve) group. Treatment rat groups with Eruca sativa leaves, juice, oil and seeds could increase values of liver antioxidant enzymes and lower MDA value compared with control (+ve) group as found in table 7.

\section{Discussion}

Medicinal plant has nutrient compositions that are essential for the physiological functions of human body. Such nutrients and biochemical's like carbohydrates, fats and proteins play an important role in satisfying human needs for energy and life. Minerals are essential for human nutrition and must be obtained from diet (Adnan et al., 2010). The obtained results of gross chemical analysis and minerals content of Eruca seeds and leaves agreed with Flanders and Abdulkarim (1985), Ellahi et al., (2007) and Muhammad et al., (2011). The improvements in nutritional and growth results represented in table 3 were related to the chemical composition of Eruca seeds and phytochemical analysis. Seeds contain various nutrients which are required for food or feed purposes. Bukhashi et al., ( 2007 ) analyzed the nutrition compounds and trace elements in both leaves and seeds of this plant. The contents of oil depend on many factors including maturity of the seeds and the degree of plant irrigation crude protein is a good source of feed supplement (Flanders and Abdulkarim 1985 and Villatoro-Pulido et al., 2012). Both essential and non essential fatty 


\section{Egypt. J. of Nutrition and Health Vol. 9 No. 1 (2014)}

acids are present in Eruca oil as Erucic acid was the main fraction found in the seed oil. Higher concentration of Erucic acid was present in both free and triglyceride form (Khoobchandani et al., 2010). Mono and polyunsaturated fatty acids like Oleic acids and linoleic acid were abundant. Presence of these fatty acids support edible uses of Eruca seeds indicating that oil contained valuable fatty acids required for edible purposes (Flanders and Abdulkarim 1985 and Alam et al., 2007).

The activities of liver function enzymes tended to decrease indicating improved liver function tests. Such reduction of liver enzyme activities and also reduction of total protein and urea concentration exhibit healthy effect of dietary rocket due to high content of sulphur and antioxidant status as reported by Alam et al., (2007)

In the present work, Eruca sativa has antihyperlipidemic, hepatoprotective and antihyperglycemic effects. These results were in agreement with Bukhashi et al., (2007). Also, the obtained results showed that Eruca sativa produced potent antioxidant and renal protective activities. Eruca sativa seeds and leaves possess a potent free radical scavenging antioxidants and protect against oxidative damage by increasing and maintaining the levels of antioxidant molecules and antioxidant enzymes (Bennett et al., 2006). Rocket and other Cruciferous vegetables contain a group of anticancer compounds known as glucosinolates, these compounds exert antioxidant activity, and are potent stimulator of natural detoxifying enzymes in the body, such compound exert anti-secretary, anti-ulcer and cytoprotective properties in the ethanolic extract of the plant in rats (Al-qasomi et al.,2009). Several studies on phytochemical analysis of Eruca sativa leaves has shown the presence of many antioxidant compounds including glucosinolate, flavonoids (Quercetin,Kaempherol and isohamnetin), carotenoids and Vitamine C (Jin et al.,2009).

Regarding the present study it could be concluded that Eruca sativa produce hepatotreatment and diuretic effects in rats as result of paracetamol induced hepatic injury in rats. These effects could be due to antioxidant activity. Therefore, the study recommends that intake of Eruca sativa seeds, oil or leaves may be beneficial for patients who suffer from liver diseases and those on paracetamol therapy. 


\section{References}

A .O. A. C. (1995):

Official Methods of Analysis,Association of Official Analytical Chemists, $16^{\text {th }}$ Ed., Virginia, U.S.A.

Adnan, M., Hussain, J. ; Shah, M. T. ; Shinwari, Z. K. ; Ullah, F. ; Bahader, A. ; Khan, N. ; Khan A. L. and Watanabe, T.(2010).

Proximate and nutrient composition of medicinal plants of humid and sub-humid regions in North-west

Pakistan. J. Med. Plant Res., 4(4): 339-345.

Alam, M.S. ; Kaur, G. ;Jabbar, Z. ; Javed K.and Athar. M. (2007).

Eruca sativa seeds possess antioxidant activity and exert a protective effect on mercuric chloride induced renal toxicity. Food and Chemical Toxicology,45 : 910-920.

Al-qasomi,S.; Al-sohaibani,M.; Al-Howriny,T.; Al-Yahya, M. and Rafatullah, S. (2009).

Rocket(Eruca sativa):a salad herb with potential gastric anti-ulcer activity.World.J.Gastroenterol.15(6):19581965.

Ansari, M.N. (2014).

Ameliorative effect of Eruca sativa extracts on glucose and urinary volume in streptozotocin-induced diabetic rats. IJBPAS, July, 2014, 3(7): 1092-1100.

Artimage, G.Y. and W.G. Berry, (1987).

Statistical Methods 7th Ed. Ames, lowa Stata University Press, 39-63.

Bennett, R.N.; Rosa, E.A.; Mellon, F.A.and Kroon, P.A.(2006).

Ontogenic profiling of glucosinolates, flavonoids, and other secondary metabolites in Eruca sativa (salad rocket), Diplotaxis erucoides (wall rocket), Diplotaxis tenuifolia (wild rocket), and Bunias orientalis (Turkish rocket). J. Agric. Food Chem., 54, 4005-4015.

Beuchamp, C. and Fridovich, J.(1971).

Superoxide dismutase. Improved assay an assay applicable to acryloamide gels. Anal Biochem., 44: 276-287.

Bukhashi, E.; Maliki, S.A. and Ahmed, S.S. (2007).

Estimation of nutritional value and trace elements content of Carthamus oxycantha ,Eruca sativa and Plantago ovanta .Pak.J.Bot., 30(4):1181-1187.

Chapman, D.G., Gastilla R. and Campbell, T.A. (1950).

Evaluation of protein in food. I. A. Method for the determination of protein efficiency ratio. Can. J. Biochem. Physio., I (37) 679-686.

Duke, J.A. and Atchley, A.A. (1984).

Proximate analysis, In: The Handbook of plant science inagriculture. (Ed.): B.R. Chrwastie. CRC Press, Boca Raton. FL. 


\section{Egypt. J. of Nutrition and Health Vol. 9 No. 1 (2014)}

Eisenberg, D.M.; Davis, R.B. ; Ettner, S.L. ; Appel, S. ; Wilkey, S. ; Van Rompay, M. and Kessler, R.C. (1998).

Trends in alternative medicine use in the United States, 1990-1997: results of a follow-up national survey.JAMA. Nov $11 ; 280(18): 1569-75$.

Ellahi, B.; Salman, A. and Sheikh, S. (2007).

Estimation of nutritional value and trace elements content of Carthamus oxyacantha, Eruca sativa and Plantago ovate. Pak. J. Bot., 39(4): 1181-1187.

Ellman, G.L. (1958).

Liver glutathione. A colorimetric method for determining low concentration of glutathione. Arch Biochem Biophys., 78: 443-450.

Flanders, A. and Abdulkarim, S. M. (1985).

The composition of seed and seed oils of taramira(Eruca sativa). Journal of the American Oil Chemists' Society, 62(7):1134-1135.

Folch, J., lees M. and Stanley, G.H. (1957).

A simple method for isolation and purification of total lipid from animal tissue. J Biol Chem., 266: 497-509.

Jendrassik, L. (1938).

Colorimetric determination of bilirubin. Biochem., 97:72-81.

Jin, J. ; Koroleva, O.A. ; Gibson, T. ; Swanston, J. ; Magan, J. ; Zhang, Y. ; Rowland, I.R. and Wagstaff, C. (2009). Analysis of phytochemical composition and chemoprotective capacity of rocket (Eruca sativa and Diplotaxis tenuifolia) leafy salad following cultivation in different environments. J. Agric. Food Chem., 57(12): 5227-5234.

Khoobchandani, M. ; Ojeswi, B.K. ; Ganesh, N. ; Srivastava, M.M. ; Gabbanini, S. ; Matera, R. ; Iori R. and Valgimigli, L.(2010).

Antimicrobial properties and analytical profile of traditional Eruca sativa seed oil: Comparison with various aerial and root plant extracts. Food Chem., 120: 217- 224.

Kind, P.R and King, E.J. (1954):

Estimation of alkaline phosphatase activity by determination of hydrolyzed phenol with aminoantipyrene. J. Clin.Path, 7: 322.

Lazzeri, L.; Errani. M. ; Leoni. O. and Venturi. G. (2004).

Eruca sativa spp.Oleifera: A new non-food crop. Ind. Crop Prod., 20: 67-73.

Lynn, A.; Collins, A.; Fuller, Z.; Hillman, K. and Ratcliffe, B. (2006).

Cruciferous vegetables and colo-rectal cancer. Proc. Nutr. Soc., 65: 135-144.

Meister, A.; Tate, S.S. and Griffith, O.W. (1981).

y-Glutamyl transpeptidase. Methods Enzymol., 77: 237-253.

Mc Inory, R.A. (1954):

A micro heamatocrit for determining the packed cell and hemoglobin concentration on capillary blood. J. Clin. Path., (7): 32. 


\section{M.F.ELSadek}

Muhammad, G. ; Alia, S. ; Hira, T. ; Muhammad, I. ; Rahmatullah, Q.and Asyia, Z.(2011).

Phytochemical analysis and antibacterial activity of Eruca Sativa seed. Pak. J. Bot., 43(2): 1351-1359.

Pasini, F. ; Verardo, V. ; Cerretani, L. ; Caboni, M.F. and D'Antuono, L.F.(2011).

Rocket salad (Diplotaxis and Eruca spp.) sensory analysis and relation with glucosinolate and phenolic content. J Sci Food Agric. ,Dec;91(15):2858-64.

Patton, C.J. and Crouch, S.R. (1977):

Enzymatic colorimetric method to determination urea in serum. Anal. Chem., 49: 464.

Pupsa, R. ; Connie M. and April, C.(1994).

Mineral bioavailability in rats from intrinsically labeled whole wheat flour of various phytate levels. J. Agric. Food Chem., 42 (11): 2531-2535.

Rafael, B. ; Daniela, F. ; Haim, S. ; Hussein, A. ; Zipora, M. ; Moshe, P. ; Liliana, Z. ; Yona, A. ; Ran, O. and Zamir, H.(1999).

Hypothyroidism protects rat liver from Aacetaminophen hepatotoxicity. Digestive Diseases and Sciences, 44(6): 1228-1235.

Reeves, P.G.; Nielsen F.H. and Fahmy, G.G. (1993).

AIN-93. Purified diets for laboratory rodents : Final report of the American Institute of Nutrition adhoc wriling committee on the reformulation of the AIN-76 A Rodent diet. J. Nutrition, 123: 1939-151.

Reitman, S. and S. Frankel, (1957).

Determination of glutamate pyruvat transaminase and glutamate oxaloacetate transaminase. Amer. J. Clin. Path., 28:56-63.

Rerup, E. and Lundquist, S.(1967).

Precipitation and purification of liver glycogen in rats .Acta Pharmmic. Tox., 25:47-51.

Richmond, N. (1973).

Colorimetric method of determination of total cholesterol and high density lipoprotein cholesterol (HDLC). Clin.Chem., 19, 1350-1356.

Sarwar, A. M. ; Kaur, G. ; Jabbar, Z. ; Javed. K and Athar, M. (2007).

Eruca sativa seeds possess antioxidant activity and exert a protective effect on mercuric chloride induced renal toxicity. Food Chem Toxicol.,45:910-920.

Scheletter, G. and Nussel, E.(1975).

Arbeitsmed Sozialmed Praventimed, 10: 25.

Stickel, F. and Schuppan, D. (2007).

Herbal medicine in the treatment of liver diseases. Dig Liver Dis. , 39(4):293-304.

Uchiyama, M. and Mihara, M. (1978).

Determination of malondialdhyde precursor in tissues by thiobarbituric acid test. Anal. Biochem., 86 (1),271278 . 


\section{Egypt. J. of Nutrition and Health Vol. 9 No. 1 (2014)}

Vankampen, E.J. and Ziglstra, W.G., (1961).

Colorimetric determination of haemoglobin. Clin. Chem. Acta., 6, 53-88.

Villatoro-Pulido,M., Moreno Rojas , R. ; Muñoz-Serrano, A. ; Cardeñosa, V. ; Amaro López, M.Á. ; Font R. and Del Rio-Celestino, M.(2012).

Characterization and prediction by near-infrared reflectance of mineral composition of rocket (Eruca vesicaria subsp. sativa and Eruca vesicaria subsp. vesicaria). J Sci Food Agric., May; 92(7):1331-40.

Weichselbaum, T.F. (1946).

An accurate and rapid method for the determination of protein in small amount of blood serum and plasma. Am .J Clin Path., (16):40.

Weiss, C.; Marker H.S. and Lehrer, G.M. (1980).

Sensitive fluorometric assays for glutathione peroxidase and reductase. Anal Biochem., 106: 512-516.

Yanir, Z. ; Schaffermann, D. and Zmar, Z. (1998).

Tradition, uses and biodiversity of rocket (Eruva sativa, Brassicaceae) in Israel. Econ Bot.;52:394-400. 
التركيب الكيميائي والنشاط العلاجى للجرجير ضد البارسيتامول المسبب لاصابة الكبد في فيران التجارب

$$
\text { محمد فاروق الصادق }
$$

قسم التغذية وعلوم الأطعمة ـ كلية الاقتصاد المنزلي - جامعة حلوان الصدان

$$
\text { الملخص العربى }
$$

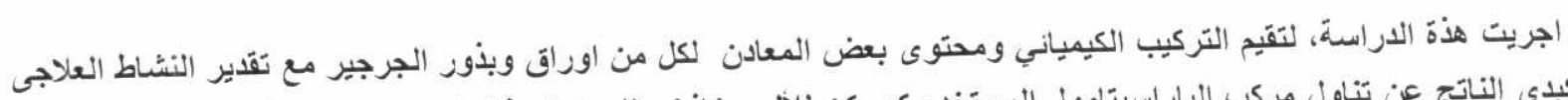

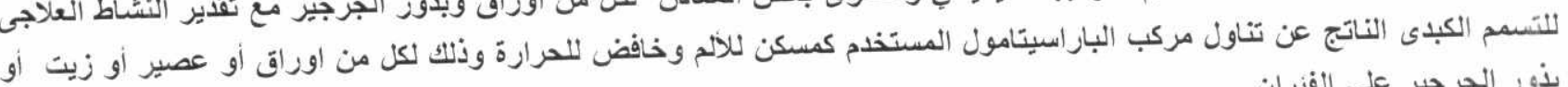
بذوز الجرجير علي الفنران. حيث اظهرت نتانج هذه الدراسة المتحصل عليها أن بذور الجرجير تحتوى على كمية كبيرة من البرونين الخام و الدهون

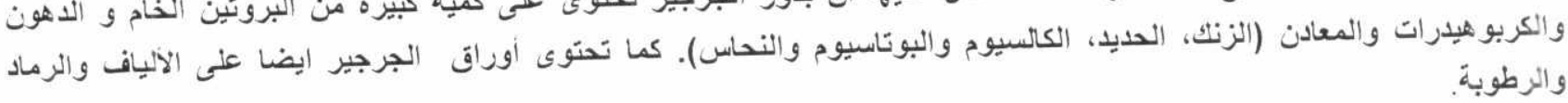
و والزطوبة

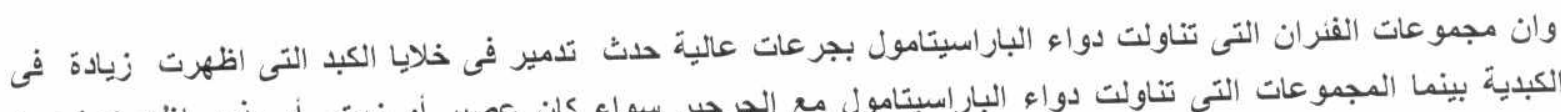

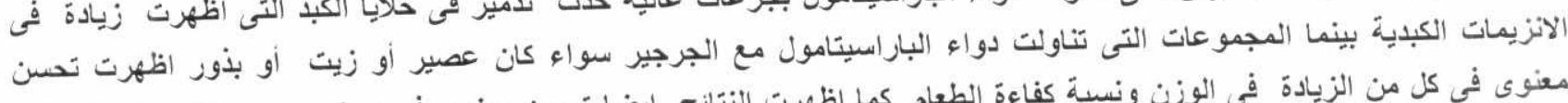

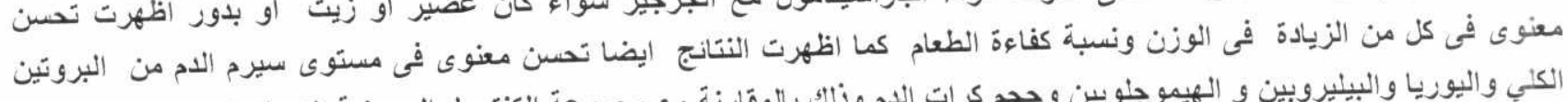

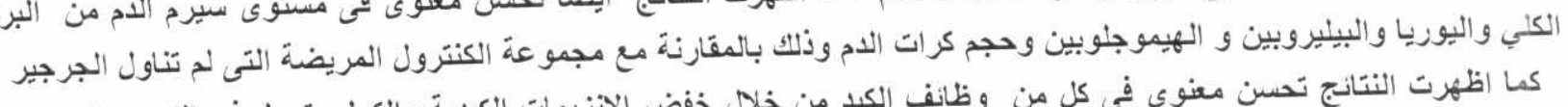

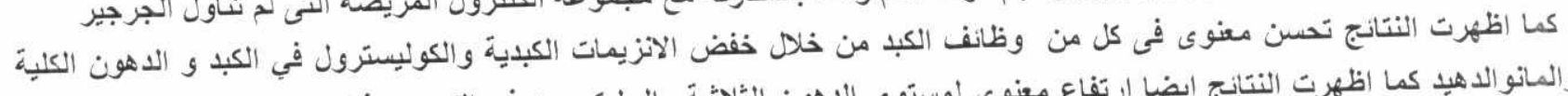

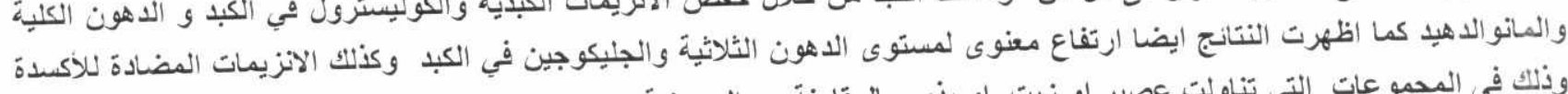

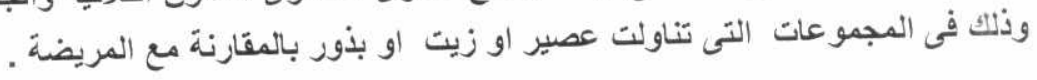

وتوصى هذة الدراسة باهمية استخدام الجرجير أو منتجاته ضمن الخطة الغذائية لمرضى الكبد وكذالتك عند المرضى اللذين

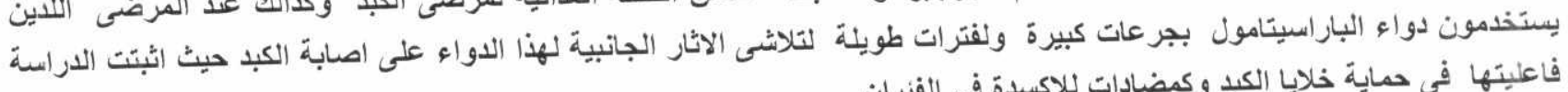

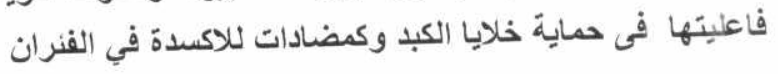

|الكلمات المفتاحية : الجرجير - إصابة الكبد- الباراسيتامول- انزيمات الكبد-مضادات الأكسدة- الفنران 